\title{
REMOTE SENSING AND HYDROLOGIC MODELING OF ARID WATERSHEDS: A SCALE ANALYSIS
}

\section{Thomas W. Gardner}

Department of Geosciences

College of Earth and Mineral Sciences

\section{Gary W. Petersen \\ Department of Agronomy \\ College of Agriculture}

\section{Final Report}

for Period July 15, 1986-August 31, 1990

Prepared for

Ecological Research Division

Office of Health and Environmental Research

the U.S. Departiment of Energy

Agreement No. DE-FG02-86ER60472

August 1990

\section{DISCLAIMER}

This report was prepared as an account of work sponsored by an agency of the United States This repor was prepared as an anter Government nor any agency thereof, nor any of their Government. Neither the Unity, express or implied, or assumes any legal liability or responsiemployees, makes any warrant, expr, or usefulness of any information, apparatus, product, or bility for the accuracy, completeness, or usefulness of any information, apparats, prods. Referprocess disclosed, or represents that its use would not infringe or service by trade name, trademark, ence herein to any specific commercial product, process, or service by trade naturesters or otherwise does not necessarily constitute or imply its endorsement, recommendation, or favoring by the United States Government or any a necessarily state of reflect those of the and opinions of authors expressed herein do 


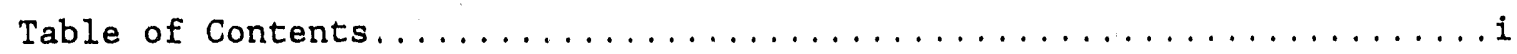

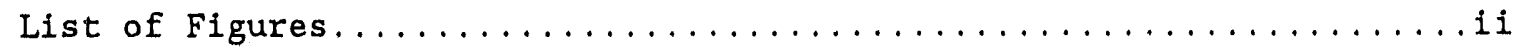

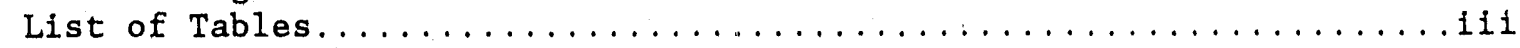

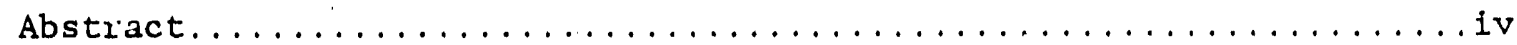

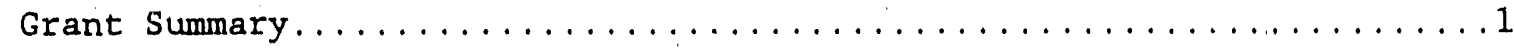

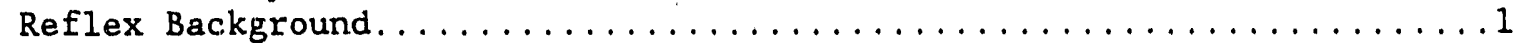

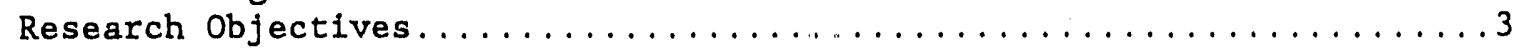

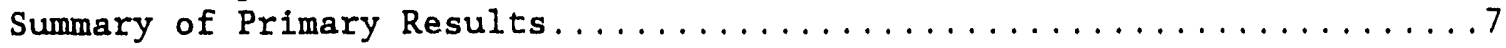

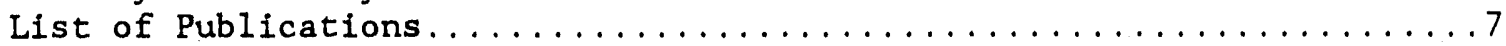

Appendix A - Research Publications ....................9 


\section{LIST OF FIGURES}

1

Figure

Page

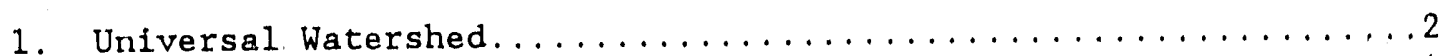

2. Existing and Proposed REFLEX sites...................

3. Location Map of the two study basins.................6 


\section{LIST OF TABLES}

\section{Table}

Page

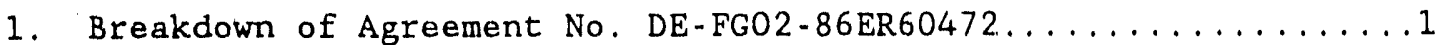

2. Description of Existing and Proposed REFLEX Sites............ 
Abstract

The increasing availability of digital elevation data (DED) created from remotely sensed data has promoted the development of computer algorithms for the calculation of geomorphometric properties of the land surface. These include parameters that are tedious or impossible to do by hand, for example, stream properties by order and flow path mapping for every location within the drainage basin. Flow paths especially are critical for water routing in hydrologic models. These algorithms can be used to explore spatial trends in landscape properties as a function of rock type, climate or neotectonic environment.

The DED can be readily linked with a geographic information system (GIS) which is used to parameterize a quasi-physically based surface runoff model. Various representations (Shreve orders) of the watershed are created by simplifying a stream network delineated from the DED. Different Shreve orders produce significantly different geomorphometrics that affect simulated runoff volumes.

At one of the study sites, the DED are not of sufficient detail to allow stream network extraction. Therefore, classification of SPOT panchromatic data was used to delineate ephemeral, fluvial networks on this low-relief, arid basin. A one pixel proximity search classified correctly over 80 percent of the channelized flow. 


\section{GRANT SUMMARY}

This final report describes research conducted under Department of Energy Agreement No. DE-FG02-86ER60472 (including Amendments A001-A005) for the project period July 15, 1986 to August 31, 1990. Specifics of the agreement are summarized in Table 1.

Table 1. Breakdown of Agreement No. DE-FG02-86ER60472

Grant No.

Award Amount

Budget Feriod

$\begin{array}{lll}86-\text { ER60472 } & \$ 80,000.00 & 7 / 15 / 86-7 / 14 / 87 \\ 86-\text { ER60472.A001 } & \$ 50,000.00 & 7 / 15 / 87-7 / 14 / 88 \\ 86-\text { ER60472.A002, 3,4,5 } & \$ 69,990.00 & 7 / 15 / 88-8 / 31 / 90\end{array}$

Award Total

$\$ 199,990.00$

\section{REFLEX BACKGROUND}

Research was initiated within and conducted under the auspices of the Remote Fluvial Experimental (REFLEX) Series Program in the Office of Energy Research, Office of Health and Environmental Research, Ecological Research Division of the department of Energy. As stated in the REFLEX. Program dated Ostober 1986, the goals of REFLEX are to:

- apply new and developing aerial and satellite remote sensing technologies--including both advanced sensor systems and digital/optical processing--to interdisciplinary scientific experiments in hydrology and to hydrologic/ecologic interactions;

- develop new concepts for processi $g$ and analyzing remote sensing data for general scientific application;

- demonstrate innovative analytical technologies that advance the state of the art in applying information from remote sensing systems, for example, supercomputer processing and analysis.

The REFLEX program was organized around the concept of the universal watershed (Figure 1) with priority given to interdisciplinary research on the hydrologic cycle. Experiments were conducted to evaluate hydrologic interactions in terrestrial landscapes and ecosystems for which historical information bases already exist or where research is in progress.

"The need for information on terrestrial systems to meet environmental health and safety requirements is increasing each year. Information concerning contaminant transport along surface and 


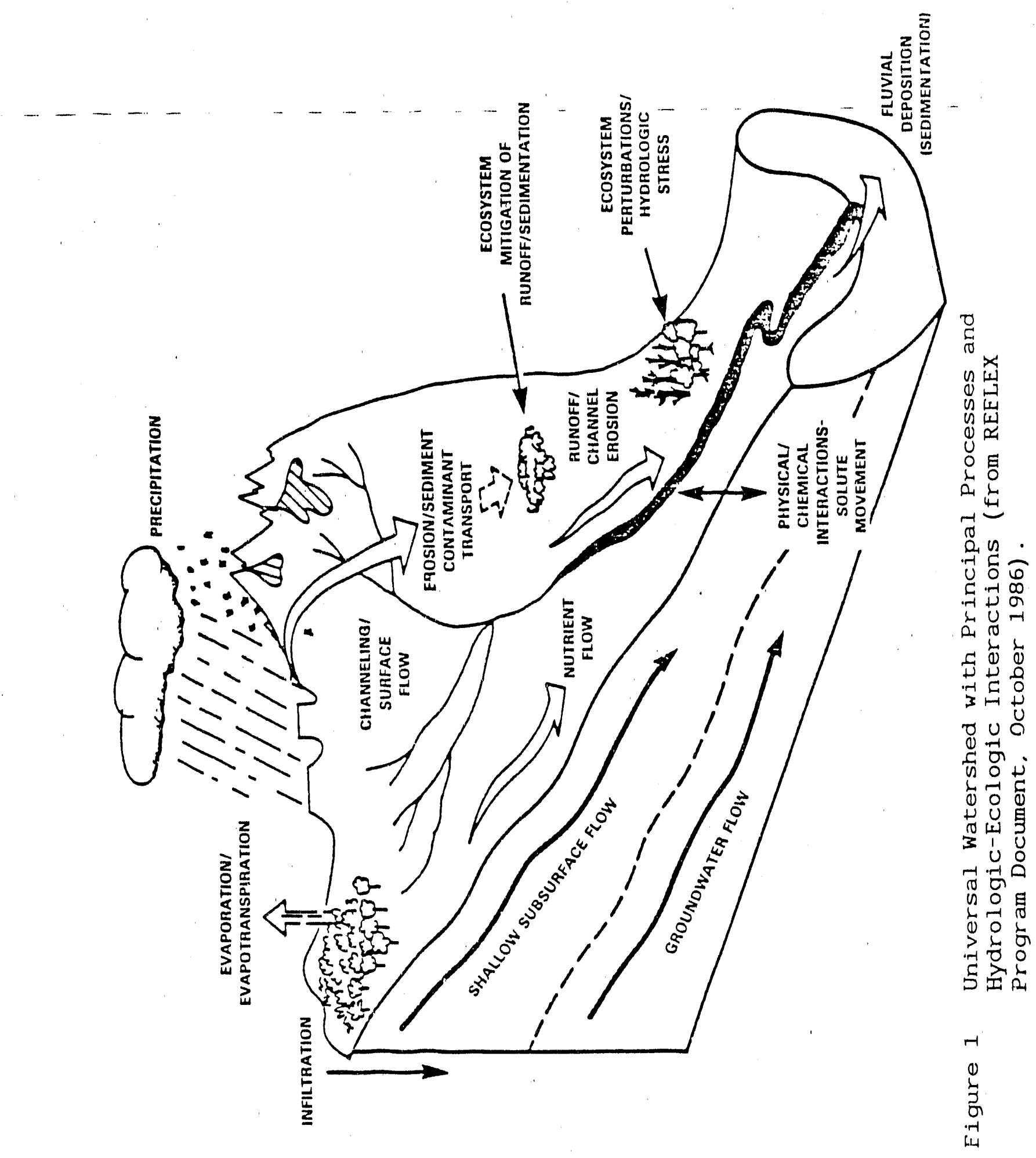


groundwater pathways is essential to anticipating and to mitigating effects on terrestrial ecosystems and on humans. The advanced technologies of REFLEX can potentially help solve environmental safety problems faced by DOE" (REHLEX Program Document, 1986). The underlying REFLEX strategy was to study uncertain or unproven scientific concepts using advanced remote sensing technologies.

To achieve the REFLEX goals, experiments were conducted under phase I of the REFLEX program. Phase I (1984-1990) which encompasses the project period of this grant emphasizes identification, exploration, and hypothesis testing of scientific questions related to the hydrologic cycle and to hydrologic/ecologic interactions. Clearly, perturbations caused by energy development or waste disposal in the long term are a general motivation fot this research. In addition, the REFLEX. experiments are being conducted within different climatic/ecological zones (Figure 2, Table 2) in an effort to explore the limits and benefits of advanced remote sensing technologies and analyses.

To achleve these REFLEX goals, Phase I research activity for this project was initiated in an arid and semiarid climatic zone. The arid zone site, at the Nevada Test Site in Nevada (Figure 3 and Table 2), was selected because of the potential for radionuclide contamination by surface transport. The semi arid site, at Walnut Gulch in Arizona, (Figure 3 and Table 2) was selected because of the extensive data base on surface hydrology provided by the U.S. Department of Agriculture.

\section{RESER 1 RCH OBJECTIVES}

The ultimate goal of this research effort was to model long-term $\left(10^{2}-10^{4} \mathrm{yrs}\right)$, cut and fill cycles in arid region fluvial systems (arroyos). Historic and geologic (late Quaternary) data bases indicate that arid region fluvial systems have oscillated between periods of pronounced aggradation and degration. This cyclic behavior has affected both water and sediment dischaxge from arid watersheds as well as ecosystem habitats along hillslopes and valley bottoms. One of the primary causes that has been proposed for this cyclic activity is climatic change for gradual (glacial-interglacial) and catastrophic (volcanic eruptions, el Nino) rates of climatic change on a global scale.

Climatic change acting through temperature changes and in amount, type and distribution of both rainfall and vegetation control the supply of water and sediment to and through a watershed. These variables, in turn, control the arroyo processes and the cut and fill cycles in arid watersheds. Prediction of arid watershed response to climatic change over both short and longer (geologic) time scales is important for DOE waste repository sites.

This research effort required a watershed scale approach which necessarily included large multilayered, digital, data sets that contained parameters for input to a watershed scale hydrologic model. It was amenable to a GIS approach which we have employed in our past research effort. The research conducted for this agreement has focused on specifically evaluating hydrologic modeling (SPUR) of observed runoff 


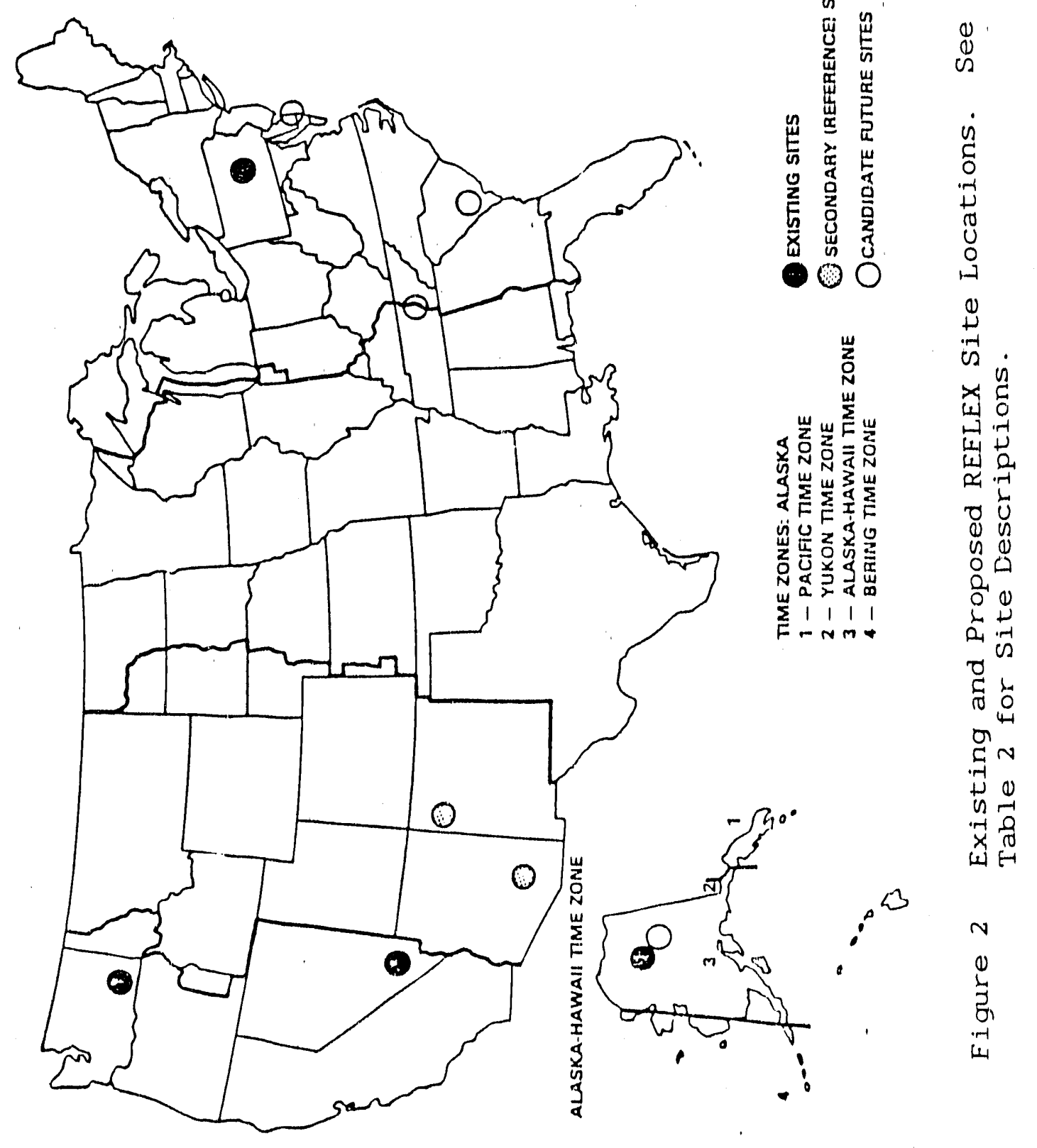




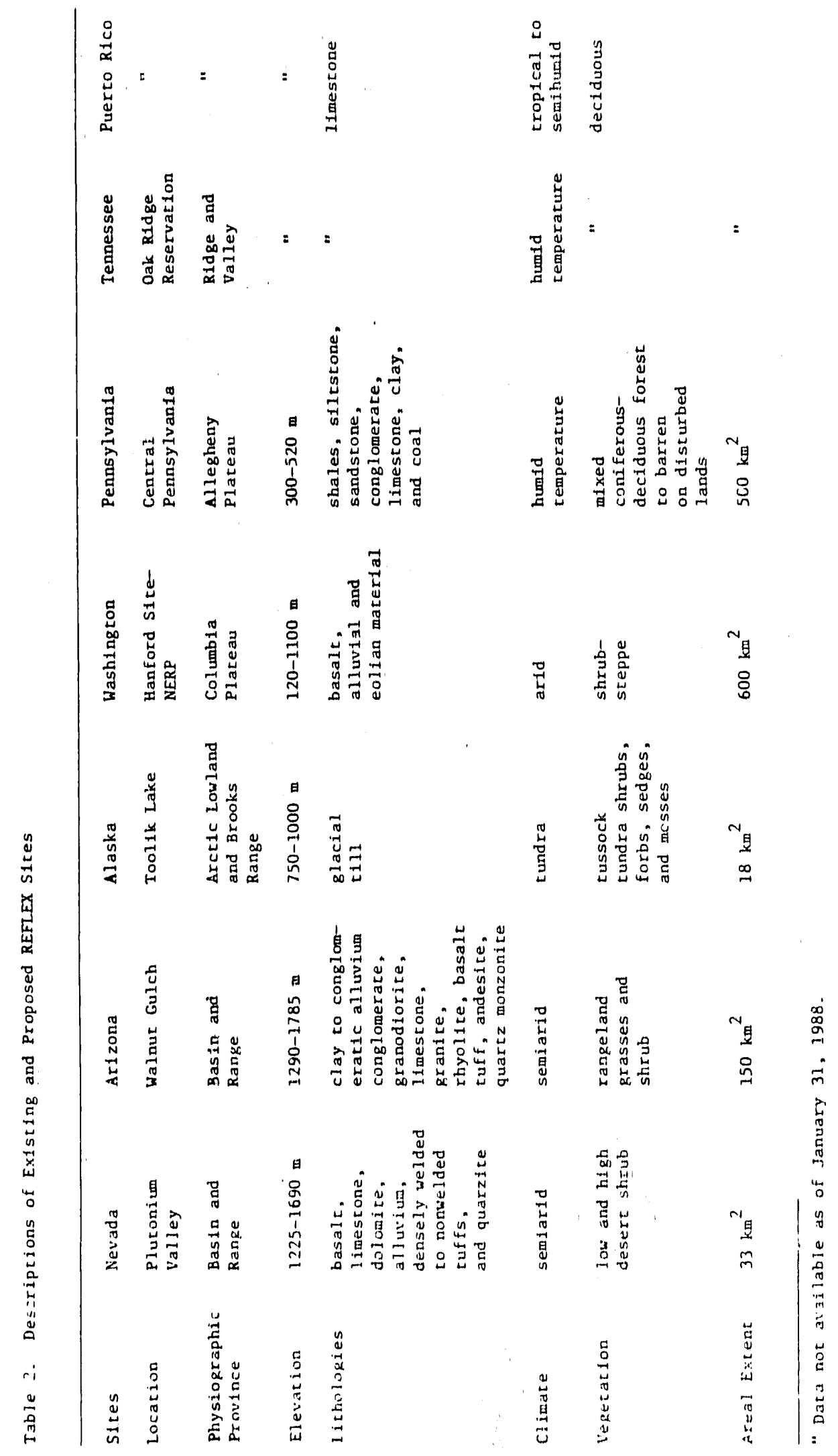




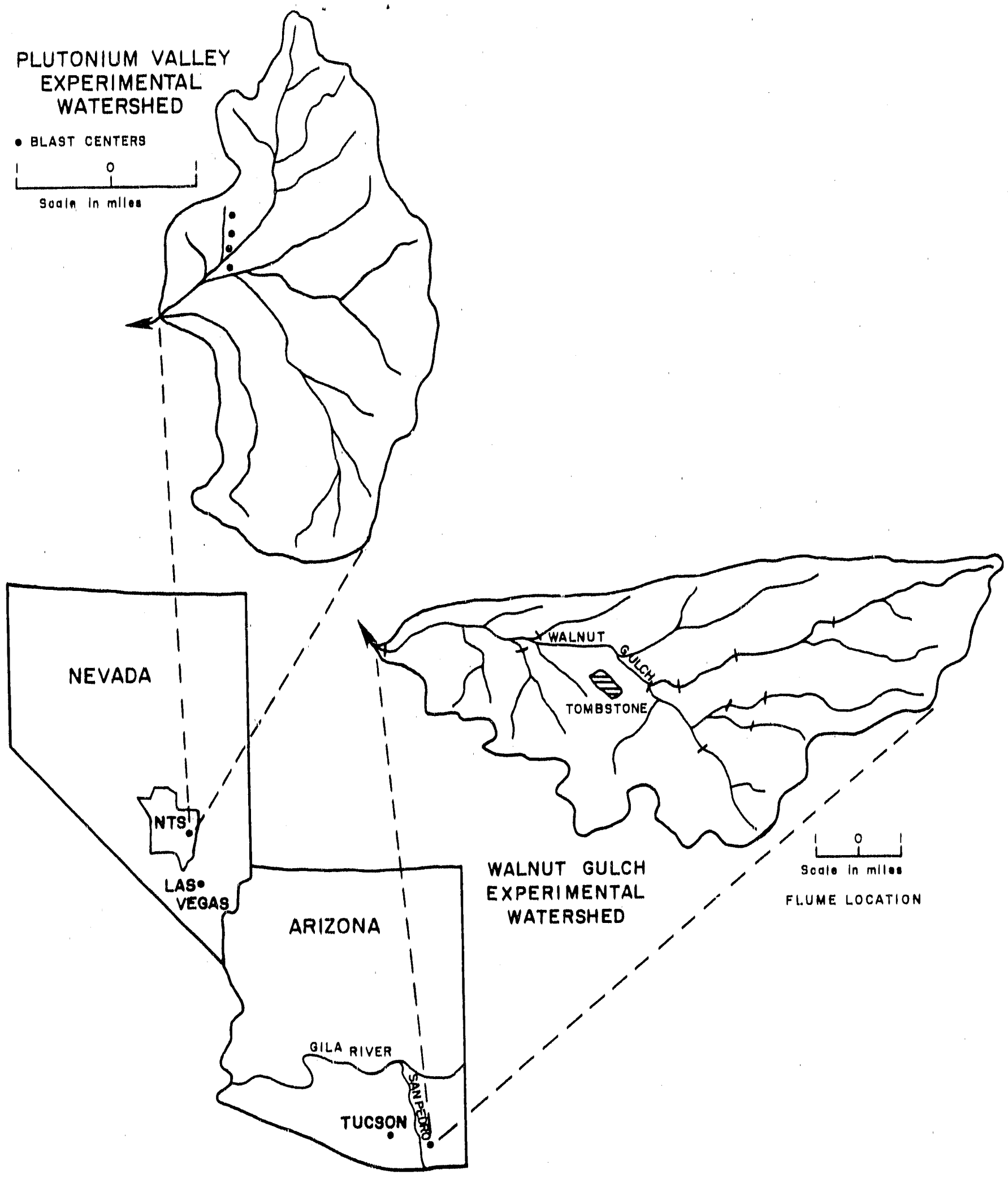

Figure 3 Location map of two study basins. 
events and general geographic information systems techniques for manipulation of remotely sensed and field-derived data sets for appropriate watersheds at Walnut Gulch, Arizona (USDA) and Plutonfum Valley (Nevada Test Site, DOE).

\section{SUMMARY OF RRIMARY RESULTS}

Significant scientific milestones accomplished during the research period are summarized below. Publications that elaborate upon these fundament,al accomplishments are itemized in the next section, "List of Publicatton." This list includes journal publications and abstracts of papers given at professional meetings. Al1 relevant journal publications are included in an nppendix to allow the reader to explore and expand upon the scientific milestone outlined below.

- Development of algorithms for extraction of topographic and channel network parameters from digital elevation models for input to hydrologic models.

- Development of algorithms for extraction of channel networks from high resolution SPOT panchromatic data on low relief alluvial fan surfaces at the Nevada Test Site.

- Development of grid-cell GIS techniques for parameterization of SPUR and sensitivity analysis to watershed discretization at Walnut Gulch, Arizona.

\section{LIS'I_OF PUBLICATIONS}

Research publication and abstracts partially or completely funded by agreement No. DE-FGO2-8GER60472.

\section{Papers:}

Gardner, Thomas W., K.F. Connors, and Haujan Hu, 1989, Extraction of fluvial networks from SPOT panchromatic data in a low relief and basin, International Journal of Remote Sensing, v. 10, pp. 1789-1801.

Connors, Kathryn F., T.W. Gardner, and R.L. Day, (1989), Deriving stream parameters for hydrologic modeling from digital elevation data, in Surface Water Modeling - New Directions for Hydrologic Predictions, IAHS Pub1. No. 181, pp. 397-406.

Gardner, T.W., K.C. Sasowsky, and R.L. Day (in press), Automated extraction of geomorphomatric properties from digital elevation models, Zeitschrift fur Geomorphologie.

Sasowsky, Kathryn C. and Thomas W. Gardner, Watershed discretization, geographic information systems and SPUK hydrology model simulations (submitted to Water Resources Bulletin, August 1990).

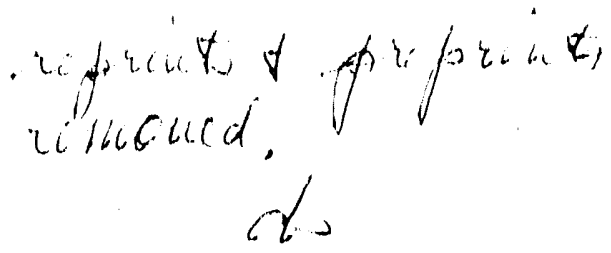


Abstracts :

Petersen, G.W., T.W. Gardner, K.G. Connors, and D. Miller, 1988, Remote Sensing in Hydrology and Ecclogy (Abs), Frontiers in Physical Sciences, American Association for Advancement of Sciences, Boston, p. 1.

Connors, K.F. and T.W. Gardner, 1988, Digital Elevation Data Resolution Effects on Slope Lengths and Gradients, Agronomy Abstracts, Annual

Meetings of the American Society of Agronomy, p. 273.

Day R.L., G.W. Petersen, T.W. Gardner, and K.F. Connors, 1988, ThreeDimensional Characterization of Drainage Basins, Using Digital Elevation Models, Agronomy Abstracts, Annual Meeting of the American Society of Agronomy, p. 255.

Gardner, T.W., R.L. Day, and K.F. Connors, 1989, Uniformiy Gridded Digital Elevation Data as Infut to Distributed-Type Hydrologic Models, American Geophysical Union, EOS, v. 70, p. 1091. (Invited).

Gardner, T.W., R.L. Day, and K.F. Connors, 1539, Automated Characterization of Watershed Parameters from Digital Terrain Data Sets, 2nd International Conference on Geomurphology, Geooko, v. 1, p. 101. 

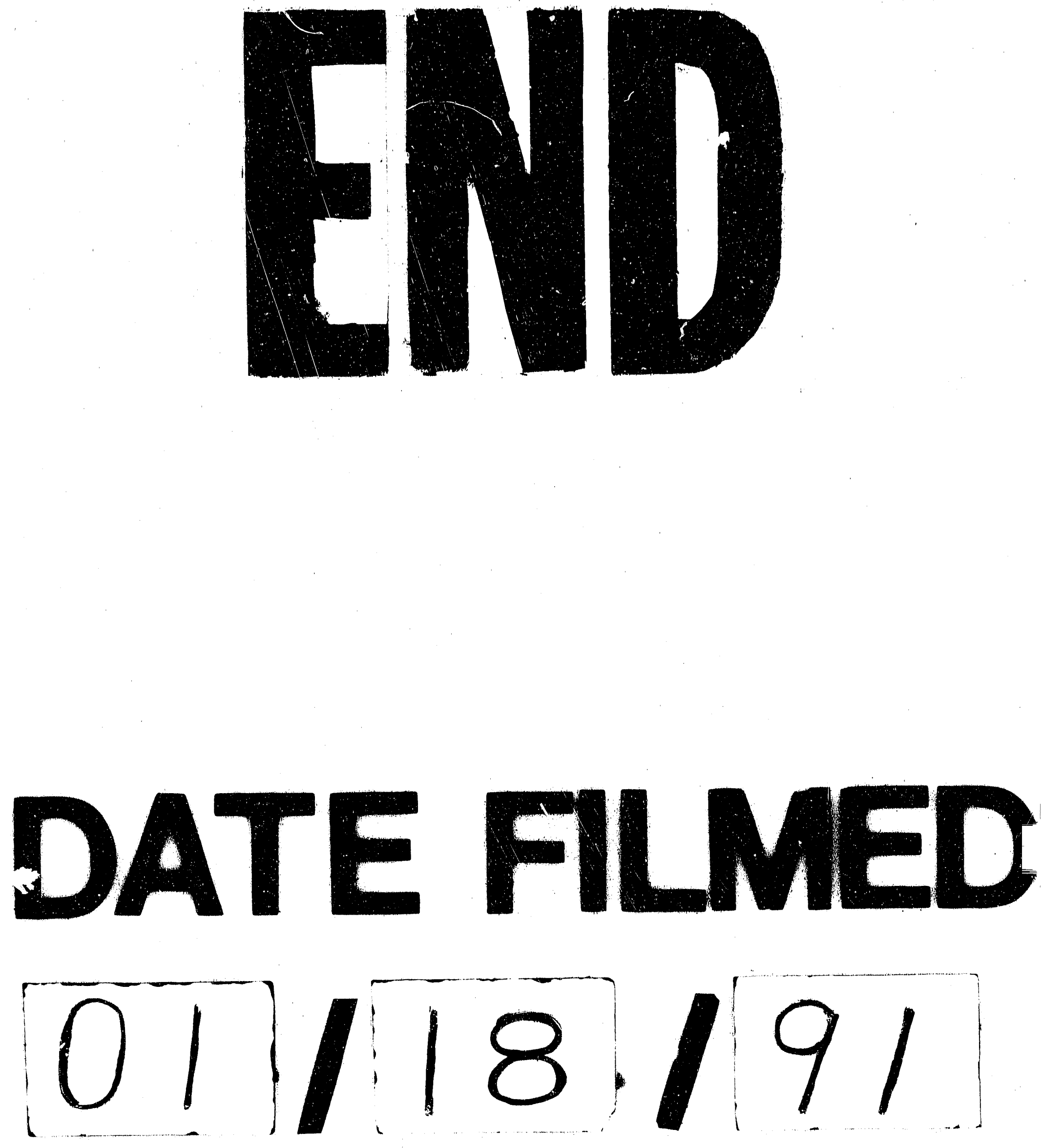
